\title{
DETERMINAN MOTIVASI KERJA DAN IMPLIKASINYA TERHADAP KOMITMEN PEGAWAI PUSDIKLAT KEMENTERIAN AGAMA REPUBLIK INDONESIA
}

\author{
Sairin $^{1}$, Hadyati Harras ${ }^{2}$ \\ Universitas Pamulang Pamulang, Banten \\ dosen01406@unpam.ac.id ${ }^{1}$, dosen01046@unpam.ac.id ${ }^{2}$
}

Submitted: $24^{\text {th }}$ July $2020 /$ Edited: $28^{\text {th }}$ Sept $2020 /$ Issued: $01^{\text {st }}$ October 2020

Cited on: Sairin, S., \& Harras, H. (2020). DETERMINAN MOTIVASI KERJA DAN

IMPLIKASINYA TERHADAP KOMITMEN PEGAWAI PUSDIKLAT

KEMENTERIAN AGAMA REPUBLIK INDONESIA. SCIENTIFIC JOURNAL OF

REFLECTION: Economic, Accounting, Management and Business, 3(4), 391-400.

DOI: $10.37481 /$ sjr.v3i2.187

https://doi.org/10.37481/sjr.v3i2.187

\begin{abstract}
The state civil apparatus is a state servant in charge of serving the community. Therefore, they are required to work professionally and integrity. To achieve good performance requires an attitude of commitment, and this is influenced by many factors including leadership, organizational culture, and work motivation. This study aims to analyze these three factors, how they affect commitment. Research methods using quantitative and path analysis. The research site at Education and Training Center of Indonesian Religion Ministry. The unit of analysis sampled was 50 people (employees who volunteered to fill out the questionnaire). The results showed that organizational culture can significantly increase employee commitment if work motivation to be mediation.
\end{abstract}

\section{Keywords: Leadership, Organizational Culture, Motivation, Commitment}

\section{PENDAHULUAN}

Sulit untuk menyangkal, jika keberhasilan suatu organisasi sangat bergantung pada sumber daya yang dimiliki, namun manusia menjadi satu-satunya faktor penentu atas keberhasilan tersebut. Fakta membuktikan, keberadaan sumber daya manusia berkualitas dapat menghadirkan kemajuan, kemampuan bersaing, dan pertumbuhan (Amalia, 2019). Tidak heran jika perusahaan-perusahaan besar segenap tenaga mempertahankan SDM potensial tersebut. Indriyanti (2018) dan Umar (2020) mengemukakan, SDM unggul mengambil peranan penting dalam setiap aktivitas organisasi, dan mereka dapat memenuhi kepuasan pimpinan serta mendorong kemajuan organisasi. Di antara ciri SDM atau pegawai berkualitas adalah memiliki sikap 